\title{
Tax as a tool support for operations in research and development in Polish enterprises
}

\author{
Arkadiusz Żabiński \\ Wroctaw University of Economics \\ Poland \\ e-mail:azabi@gazeta.pl \\ Elżbieta Pohulak-Żołędowska \\ Wroctaw University of Economics \\ Poland \\ e-mail: elzbieta.pohulak-zoledowska@ue.wroc.pl
}

Abstract. The article presents the issues associated with the use of tools of fiscal policy to support research - development in enterprises. Presents the economic justification for this support and the importance of the process of rebuilding the economy. Discussed possible to apply to the tax system design solutions enable companies to reduce the impact of negative factors in their research. Presented and evaluated the solutions available in the Polish tax system. The article ends with recommendations for reform of the tax system elements in Poland, which are responsible for the increase in business activity in the area of $\mathrm{R} \& \mathrm{D}$.

Received:

June, 2014

1st Revision:

September, 2014

Accepted:

October, 2014

DOI:

$10.14254 / 2071-$ $8330.2014 / 7-3 / 11$

Keywords: tax system, fiscal policy, economic growth, tax deductible, R\&D, firms

JEL Calcification H25, H39

\section{INTRODUCTION}

In a catalogue of instruments of state's economic policy, supporting economic growth based on the development of industries and services, a more significant role plays tax tools. They stimulate enterprises to an increase of expenditures on research and development, thanks to which they are to reach a competitive advantage in a globalizing economy.

The application of tax system in the accomplishment of economic and social objectives is widely described in the subject literature, and preferences included in tax constructions play an important role, in among others transformations of structural economies of Middle-East Europe. Popularity of the application of tax construction elements in a support of enterprises' pro-development policy is based on, next to verified efficiency, relatively easy procedure of applying such solutions. The application of already existing tax system enables to decrease cost of implementing such solutions, on a central as well as enterprise level. Further feature of such tools is an ease in the choice of enterprises' research-and-development activity direction. In 
contrast to subsidy or preferential credits, entrepreneurs benefiting from tax preferences can easily shape their development policy.

Application of tax construction to support research-and-development activity allows all enterprises groups in a certain economy to benefit from such solutions, regardless of their size or geographical location. In relation to subsidy, these are the tools much more popular and only slightly based on subject or object administrative decisions.

Tax preferences aiming at increasing inputs of private sector on research and development are applied by a bigger group of countries. Among countries belonging to OECD in 1995, there used to be 12 countries, and in 201126 ones (OECD, 2011). From the above mentioned solutions also Brazil, China, Russia, India, Singapore and the Republic of South Africa used to benefit from.

Tax relief connected with the activity of $\mathrm{R}+\mathrm{D}$ enables an enterprise to decrease tax reliefs, or other administration and legal burdens. One should also emphasize that, these are the preferences after researchand-development expenditures. One can assume that in contrast to direct support in the forms of subsidy $\mathrm{R}+\mathrm{D}$, tax reliefs have indirect character. Particular countries in a different level, benefit from indirect and direct tools in order to rise their economy's competitiveness through its increase of innovativeness. Moreover, about a significance of tax reliefs says the level of their application in such countries like: Australia, Austria, Belgium, Canada, Denmark, France, Ireland, Japan, Korea and Holland, where support through tax system exceeded direct support in the forms of subsidy and bailout.

The purpose of this article is to demonstrate the validity of the provision of support to enterprises in $\mathrm{R}$ $\& \mathrm{D}$ activities, to present elements of the tax system, which can be used to identify the causes of inefficiency and fiscal tools for increasing investment in research and development.

For the realization of the objectives carried out a critical analysis of the literature. The analysis of legal acts

\section{LITERATURE REVIEW OF R\&D}

Researches based on statistical data proves that, investing in $\mathrm{R}+\mathrm{D}$ is a crucial factor of economic growth (CBO, 2005). Analyses prepared by the United States House Committee on the Budget showed that, investments in research and development are nearly as efficient as investments in capital goods (CBO, 2005). It is so, because of the total productivity growth of productive factors. In a group of seven industrialised countries: the USA, Japan, Germany, France, Great Britain, Italy and Canada in the period of 1971 - 1990, each $100 \$$ invested in $\mathrm{R}+\mathrm{D}$, led to the growth of GDP by $123 \$$ (Coe, Helpman, 1995). Research conducted on the basis of the member countries in the period of 1980 - 1998, allows to claim that, each $100 \$$ additionally spent in enterprises on research and development increased GDP of a certain country by about $113 \$$ (Guellec, De La Potterie, 2001).

Research-and-development investments also bring social benefits. These benefits treated as external effects are often bigger than investments returns, gained from enterprises themselves.

External effects can be of double-sided kind: as a transfer of knowledge or financial benefits. On the ground of knowledge transfer there is, among others, impossibility of a total blockade of knowledge and information flow by patent protection. As a result, investment of one company can speed up creating knowledge by other companies. Application of gained knowledge from others, allows to improve competitiveness of a certain enterprise through increasing efficiency and product or process modifications. Knowledge transfer contributes to improvement of market position for bigger number of enterprises than these ones, which were engaged in research-and-development activities. 
From the perspective of an enterprise receiving external knowledge, transfer can come from:

- enterprises from the same branch,

- enterprises from other branches,

- universities,

- public research institutions,

- enterprises, universities, institutes from other countries.

Empirical research allows to identify several significant features of knowledge flow. Knowledge transfer is particulary crucial in branches which base their development on $\mathrm{R}+\mathrm{D}$ expenditures and highly-skilled employees (Audretsch, Feldman, 1996). The stronger knowledge flows, the less distance is between a subject generating knowledge and enterprises being its recipients. Although, it also depends on the forms of widespreading knowledge, still a basic significance has a physical distance (Fleming, King, Juda, 2007). It is possible to explain this through the meaning of work's easiness change by specialists from a certain field, and through the meaning of interpersonal contacts. Such a thesis seems to confirm geographical location of many industrial clusters, which developed in the neighbourhood of one or more universities (Audretsch, Feldman, 1996).

Indirect financial effects take place when knowledge generated in a certain subject influences on financial results of a run business activity of other enterprises. Such a statistical phenomenon is often difficult to distinguish, although its influence on all branches is undeniable. About side financial effects $\mathrm{R}+\mathrm{D}$, one can say, when a consumer or an enterprise acquires improved products thanks to research-and-development expenditures. An assessment conducted on the basis of productivity or usability growth by a buyer is higher than a market price, which is taken by a seller (Griliches, 2002). Computers and telephones constitute an example of goods, which brought benefits on the level of communities and economies, and the benefits only in a limited level were taken by enterprises, which did these innovations. Observation of variable costs in enterprises benefiting from innovations studied by others, shows that, it is a principal source of enterprises' development. Research carried out in a group of American enterprises introduce that, such savings can even arise to $1000 \%$ (Bernstein, Nadiri, 1988).

Social benefits are difficult to measure. As a sum of benefits resulting from knowledge transfer and external financial effects, they are much bigger than private effects of expenditures given for research and development. Averaged assessments of researchers concerned with this problem, allow to define private benefits in relation to the benefits of social expenditures R+D for 2 to 1 (Hall, Mairesse, Mohnen, 2012).

Existence of big social returns of investments directed to research and development is a crucial argument to run active economic policy directed toward the support of this process. Lack of countries' support will lead to less interest of enterprises about investments in $\mathrm{R}+\mathrm{D}$. Their decisions in this direction will be dictated only by private returns, omitting social benefits.

There are three single, however combined with each other types of research: basic, applied and development ones. Basic research are conducted in order to widen general knowledge. Direct application of such knowledge by enterprises can be made hard in the first period after getting the results of such research. Thus, financing such kind of research more often lies on public units..

Applied research consists in knowledge development in order to accomplish certain needs resulting from economy development, or particular branches. An example of such research can be works on graffen, thanks to which one will get, among others, further miniaturization of electronic devices. Applied research in a big extent, is interested in private sector. Direct engagement of public sector is often connected with the aims of health protection or defensive capability. 
Development research consist of application of knowledge to create certain goods and services. They usually encompass project activities, constructing prototypes and implementing goods to production, which are to accomplish certain financial aims, set by enterprises.

In most of developed countries, within sources financing research-and-development works, one can notice a certain tendency. The biggest public support is directed to basic research sector, next one is support for applied research, the lowest one is for development research. In the USA in 2008 this division was 38\% for basic research, 34\% for development ones, and 28\% for applied research (Tyson, Linden, 2012). .

\section{CONSTRUCTION TAX BENEFITS OF R \& D}

Implementing tax preferences for enterprises spending some financial means on research and development, legislators can choose from several groups of solutions. They can be adjusted to recipients depending on the aims government would like to achieve. Among tax solutions, which can be applied, one can distinguish the following ones:

1. Stepped up amortization system of investment (machines, devices, buildings, intangible and legal values) used for research-and-development activity.

2. An increase of an indicator of costs' deductions, qualified from the tax base. Such solutions allow to assign costs of earning income more than $100 \%$ of incurred expenditures on $\mathrm{R}+\mathrm{D}$ activity. In Great Britain for large enterprises, this indicator is $130 \%$, and for enterprises coming from middle and small enterprises sector it comes to $175 \%$.

3. Reliefs from tax burdens and tax free employees' remuneration, employed in $\mathrm{R}+\mathrm{D}$ activity in an enterprise. There are also known different kinds of tax reliefs for employees from abroad, employed in $\mathrm{R}+\mathrm{D}$ departments.

4. Tax reliefs allowing enterprises to deduct certain part of their expenditures on $\mathrm{R}+\mathrm{D}$, not from the tax base but from tax obligation itself.

Except from the above mentioned tools in legislation of some countries, different kind of synthetic tools are applied. One of the most interesting one is so called, box patent, which is to combine reliefs in research-and-development activity with reliefs in tax from incomes generated from registered patents in a certain country. Box patent was implemented firstly in Holland and Belgium in 2007 and then in Spain and Luxemburg in 2008.

In the case of reliefs from tax, there are two systems serving to calculate a deduction amount. The first way is to deduct all means spent on research and development. The second one is to deduct from tax only accrual of expenditures $\mathrm{R}+\mathrm{D}$, which took place in an enterprise in a certain year, in relation to the previous one. One can say that, the second way is more motivating. It rewards the activity of enterprises tending to widen research-and-development areas.

Next choice made by legislator is to define activities qualifying to tax deductions. Definition $\mathrm{R}+\mathrm{D}$ differs between countries (OECD, 2010) primarily with an expenditure catalogue, which is qualified to benefit from selected preferences. Relatively narrow definition is in force in Holland. It allows to include into expenditures qualified different kind of remunerations connected with $\mathrm{R}+\mathrm{D}$. More generous systems include also current costs and capital amortization. Although, there were few attempts to standardise expenditure catalogue qualified to $\mathrm{R}+\mathrm{D}$, still every country, according to its own needs, creates its catalogue.

Next element which helps to construct tax reliefs constitute deduction limits. They can concern a percentage volume of all expenditures on research and development, which can be deducted from accrued tax. This percentage varies in particular countries: from 10\% in Italy, 18\% in Holland, 20\% in Canada and 
Korea, up to 30\% in Spain and France. Another different solution is tax deduction from its base, which in e.g. Great Britain comes to $175 \%$ (OECD, 2009)

The second limit can concern a maximal amount of tax relief, which can be used within a tax year.

Limits can also have digressive character. It happens so e.g. in France where one can deduct from tax $30 \%$ of expenditure $\mathrm{R}+\mathrm{D}$, but after exceeding threshold of 100 million Euros expenditure, only 5\% (OECD, 2009).

Next construction element in research-and-development reliefs is an object range. Many tax systems distinguish particular groups of enterprises, relatively increasing or decreasing the range of applied preferences. In Canada, Japan, Norway, Holland and Great Britain enterprises from small and medium groups are preferred. Increased range of preferences can also concern newly-created enterprises, as it is in France.

Often met tax preferences concern enterprises cooperating in activities $\mathrm{R}+\mathrm{D}$ with higher education posts. It can also concern reliefs connected with payments for university, as well as with the reduction of tax reliefs while employing science representatives in relation to projects, which are being accomplished. Subject preferences are more seldom met, from the view of certain sectors. Such solutions most often concern kinds of technology, which is going to be taken into research, as e.g. alternative energy sources application. There can also be defined an area of research and development as e.g. biotechnology or nanotechnology. Problems with the application of such elements in tax reliefs construction result from complications connected with the interpretation of tax regulations, for the enterprise itself, as well as for fiscal institutions.

Object diversification can also have geographical character. It most often concerns state or province. In Italy, southern regions have a bigger level of preferences than in northern regions. In the USA, particular states can define the range of tax credit in accordance with $\mathrm{R}+\mathrm{D}$ activity.

Next element of tax reliefs construction can be defined by legislator, as a period through which, one can deduct from tax, or tax base, expenditures connected with $\mathrm{R}+\mathrm{D}$ activity. Costs deduction from a particular year can be possible only in a this year or in further years. Several years settlement is beneficial for companies bringing a loss in a particulary tax year.

Last recommendation concerning tax relief, connected with expenditures on research and development is stability of assumed solutions. Although, this recommendation results from the catalogue of tax rules, it is still actual. Effectiveness of applied tools will be closely connected with stability of tax system and clearness of assumed solutions.

\section{THE FUNCTIONING OF THE TAX BENEFITS OF R \& D IN POLAND}

Tax preferences role is to stimulate enterprises to increase inputs on research and development. In a consequence it will bring benefits for themselves, through the rise of competitiveness, as well as for the whole economy, through external effects.

Enterprises' expenditure on $\mathrm{R}+\mathrm{D}$ have a complementary character in relations to public expenditures. Enterprises and government's rules in the vast majority decide about expenditure level on research and development of particular country. 
The level of expenditure of the country for research and development in relation to GDP in 2007-2011

\begin{tabular}{|l|c|c|c|c|c|}
\hline & 2007 & 2008 & 2009 & 2010 & 2011 \\
\hline -EU 28 & 1,84 & 1,91 & 2,01 & 2,00 & 2,04 \\
\hline Czech & 1,37 & 1,3 & 1,35 & 1,40 & 1,64 \\
\hline German & 2,53 & 2,69 & 2,82 & 2,80 & 2,89 \\
\hline Estonia & 1,08 & 1,28 & 1,41 & 1,62 & 2,37 \\
\hline France & 2,08 & 2,12 & 2,27 & 2,24 & 2,25 \\
\hline Hungary & 0,98 & 1,00 & 1,17 & 1,17 & 1,22 \\
\hline Poland & 0,57 & 0,60 & 0,67 & 0,74 & 0,76 \\
\hline Slowenia & 1,45 & 1,66 & 1,85 & 2,10 & 2,47 \\
\hline Finland & 3,47 & 3,70 & 3,94 & 3,90 & 3,80 \\
\hline USA & 2,62 & 2,76 & 2,81 & 2,73 & 2,67 \\
\hline China & 1,40 & 1,47 & 1,70 & 1,76 & 1,84 \\
\hline Japan & 3,46 & 3,47 & 3,36 & 3,25 & 3,35 \\
\hline
\end{tabular}

Source: Eurostat, http://epp.eurostat.ec.europa.eu/portal/page/portal/science_technology_innovation/data/main_tables, date of collection 15.05.2014.

Expenditure level on research and development in relation to GDP in Poland is the lowest one in a group of analysed economies. At the average EU-28 being in an interval from 1,84 to 2,04, in Poland this indicator was from 0,57 to 0,76 . Simultaneously, expenditures $R+D$ in 2007 were the lowest ones among all gained indicators. The highest expenditures in relation to GDP were noted in Finland, where in 2009 the indicator came to 3,94 .

One of the ways to rise a level of inputs on $\mathrm{R}+\mathrm{D}$ were supposed to be in Poland, tax preferences. Application of tax system to support enterprises in their research-and-development activities, takes place through a tax relief on purchasing new technologies. This relief has a character of deducting expenditures from a tax base in income tax from natural person or legal person, depending on the forms of running business activity (Journal of Law, 2011), (Journal of Law, 2012).

Technological knowledge is considered to constitute new technologies, in the forms of intangible and legal values, particulary research-and-development work's results, which enable to create or improve new products or services. A condition to accept expenditure to purchase new technologies is an opinion of an independent scientific unit, saying if this is innovative and is not applied in the world for the period longer than 5 years.

A base to establish the sum of deduction, is an amount of incurred expenditures to purchase new technologies in a year when this new technology was implemented to fixed asset account, and intangible and legal values in a year after. In a situation, when a tax payer has a loss for a tax year, or if amount of income from non-agricultural activity is lower than amounts of deductions which are owed, then deductions relatively in the whole sum or in its left part is done in the period of three further tax years, counting from the end of year, when new technology was implemented into account.

An important construction's element to purchase new technologies is a limit coming to $50 \%$ of expended amount. At the same time, a tax payer loses a right to a tax relief in the case, when before the period of three tax years from the purchase of new technology, he/she will allow to benefit from it by other business entities, or when bankruptcy will be announced, or when he/she will get a refund of any expenditures for new technology purchase, in any form. 
Rating a construction of a tax relief connected with expenditures on research and development, against a background of other such type solutions functioning in the world, one should distinguish few characteristic solutions. First of all, a relief characterizes by a narrow object range. A purchase of modern technologies does not encompass fixed assets, or current expenditures connected with research works. Current expenditures, including employees' remuneration, cost of foreign services, consumption of material or energy, constitute $69 \%$ of expenditures paid by enterprises on research and development. Left $31 \%$ constitute capital expenditures, including among others expenditures of tangible assets, intangible or legal values (GUS, 2013). Next difficulty in a tax relief application is an opinion of scientific unit about innovativeness of purchased technology. One should realise enterprises' constraints, especially from small and medium enterprise sector, in possibilities to gain such an opinion and responsibility, which a scientific unit has to take giving a certain certificate. Such a certificate has to fulfill particular formal requirements, closely controlled by Treasury authorities (Pit.pl, 2014). However, a possibility to account for this tax relief should be positively assessed in the period of three further years, in the case when a tax payer has a loss.

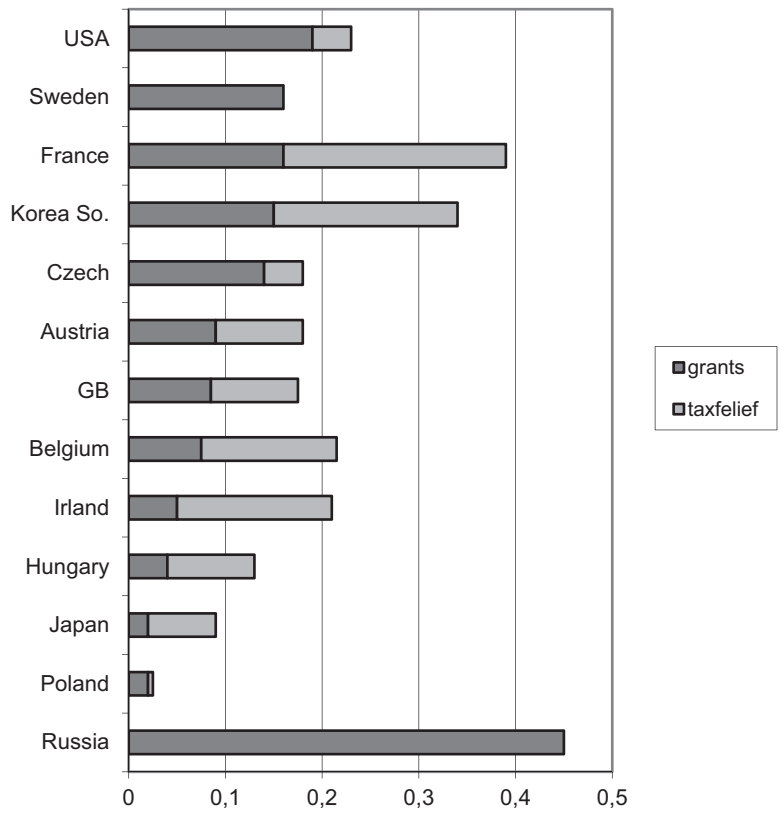

Figure. 1. Government financial support for R \& D spending in enterprises in 2010 as $\%$ of GDP Source: OECD Science, Technology and Industry Scoreboard 2011, Tax incentives for business R\&D, http://dx.doi.org/10.1787/sti_scoreboard-2011-en

Constraints included in a tax relief construction in Poland translate to low level of their use.

Poland has one of the lowest indicators of research-and-development support for enterprises by government, among OECD countries and Russia. Support forms, in a significant majority are based on government subsidies, given for particular projects. While an indicator of subsidy level for enterprises in relation to GDP, does not diverge from the support level in Japan, then a support level through tax reliefs is lower than 
in economies benefiting from such a form. From data, which were made available by Direct Tax Department of Ministry of Finance ${ }^{1}$ results that in 2012, 42 enterpreneurs paying income tax from natural persons and 94 enterprises paying CIT benefited from reliefs for purchasing technologies. In the years, when a tax relief was in force, the biggest number of tax payers paying PIT benefited from it in 2006, and it was 5297of enterprises. The least number of those benefiting from a tax relief was in 2008, only 11 enterprises. An average amount of deduction, in the case of PIT, came to 600 zlotys in the period of 2006 - 2007, up to 4600 zlotys in 2008. In the case of enterprises accounting for income tax from legal persons, the number of subjects benefiting from a tax relief fluctuated from 12 in 2006 to 26 in 2008. An average amount of deduction was definitely higher, and came to from 233000 zlotys in 2007 to 815000 zlotys in 2006.

Ineffectiveness of a tax relief to purchase new technologies, as a tool stimulating an enterprise to the growth of inputs on $\mathrm{R}+\mathrm{D}$, is noticed not only in an extremely low level of applying this relief, but also in the level of enterprises' engagement in development activity against background of institutions running activity $\mathrm{R}+\mathrm{D}$.

Table 2

The share of corporate spending in total spending on research and development in $\%$

\begin{tabular}{|l|c|c|c|c|c|}
\hline & 2007 & 2008 & 2009 & 2010 & 2011 \\
\hline EU 28 & 54,9 & 54,8 & 54,1 & 53,7 & 54,9 \\
\hline Czech & 47,2 & 45 & 39,8 & 40,8 & 37,7 \\
\hline German & 68,1 & 67,3 & 66,1 & 65,6 & 65,6 \\
\hline Estonia & 41,6 & 39,8 & 38,5 & 43,6 & 55 \\
\hline France & 52,3 & 50,8 & 52,3 & 53,5 & 55 \\
\hline Hungary & 43,9 & 48,3 & 46,4 & 47,4 & 47,5 \\
\hline Poland & 34,3 & 30,5 & 27,1 & 24,4 & 28,1 \\
\hline Slowenia & 58,3 & 62,8 & 58 & 58,4 & 61,2 \\
\hline Finland & 68,2 & 70,3 & 68,1 & 66,1 & 67 \\
\hline USA & 64,9 & 63,7 & 41 & 61 & 71,7 \\
\hline China & 70,4 & 71,7 & 71,7 & 75,9 & 60 \\
\hline Japan & 77,7 & 78,2 & & & 73,9 \\
\hline
\end{tabular}

Souce: Eurostat, http://epp.eurostat.ec.europa.eu/portal/page/portal/science_technology_innovation/data/main_tables, date of collection 15.05.2014.

Enterprises functioning in Poland spend the least number of means on $\mathrm{R}+\mathrm{D}$ activity among the introduced economies. At the EU average, exceeding 50\% of engaged means in a particular country on $\mathrm{R}+\mathrm{D}$, Polish enterprises reached the highest level of 34,3\% in 2007. At the same time in 2010 this level was the lowest one from all economies and came to $24,4 \%$. The highest indicator of enterprises' engagement in $\mathrm{R}+\mathrm{D}$ works of a certain country, showed in Europe some enterprises from Finland, in the world Japanese enterprises reached an indicator of $78,2 \%$ in 2008.

On the contrary to enterprises, contribution of government expenditures, expenditures on $\mathrm{R}+\mathrm{D}$ of all subjects from a certain country, in Poland it is very high.

1 Journal no. DD1/8213/13/SSJ/2014/RWPD-33343 dated 8.03.2014. 
The share of government spending in total spending on research and development in $\%$

\begin{tabular}{|l|c|c|c|c|c|}
\hline & 2007 & 2008 & 2009 & 2010 & 2011 \\
\hline EU 28 & 33,3 & 33,8 & 34,9 & 34,8 & 33,4 \\
\hline Czech & 44,7 & 44,8 & 47,8 & 44,7 & 41,7 \\
\hline German & 27,5 & 28,4 & 29,8 & 30,3 & 29,8 \\
\hline Estonia & 45,6 & 50 & 48,8 & 44,1 & 32,8 \\
\hline France & 38,1 & 38,9 & 38,7 & 37,1 & 35,4 \\
\hline Hungary & 44,4 & 41,8 & 42 & 39,3 & 38,1 \\
\hline Poland & 58,6 & 59,8 & 60,4 & 60,9 & 55,8 \\
\hline Slowenia & 35,6 & 31,3 & 35,7 & 35,3 & 31,5 \\
\hline Finland & 24,1 & 21,8 & 22 & 25,7 & 25 \\
\hline USA & 29,1 & 30,2 & 34 & 32,5 & 33,4 \\
\hline China & 24,6 & 23,6 & 32,5 & 24 & 21,7 \\
\hline Japan & 15,6 & 15,6 & 23,4 & 17,2 & 19,1 \\
\hline
\end{tabular}

Source: Eurostat, http://epp.eurostat.ec.europa.eu/portal/page/portal/science_technology_innovation/data/main_tables, date of collection 15.05.2014.

At the EU average - 28 which amounted in a researched period below 35\%, in Poland this indicator exceeded 55\%, reaching in 2010 maximum in a surveyed group, it is 60,9\%. Simultaneously, a high indicator of Japanese enterprises' engagement in $\mathrm{R}+\mathrm{D}$ was connected with a low level of country's expenditures in this area. Expenditure of government sector in relation to inputs on research and development in Japan in 2007 and 2008, were the lowest ones in a surveyed group, and came to only 15,6\%.

\section{SUMMARY}

Polish economy is under the process of changes. From economy based on traditionally understood production to economy based on modern services, among which research and development plays an important role. Because of a scale of changes, this transformation has huge significance for durable economic growth. Therefore, projecting further actions, one should take into account a need to create regulations stimulating enterprises to rise their expenditure on $\mathrm{R}+\mathrm{D}$, which in comparison with government expenditures are currently one of the lowest ones in the European Union.

Currently, regulations within tax preferences in income tax from natural and legal persons did not fulfill hopes believed in them. Among a number of possible construction elements of tax relief, supporting expenditures for $\mathrm{R}+\mathrm{D}$ of enterprises, a legislator applied only a few. A cause of residual application of a tax relief to purchase new technologies is a narrow object range. From a report, "Research and development in Poland. Report 2013", results that $32 \%$ of surveyed enterprises do not benefit from a tax relief, because of constraints of expenditure catalogue, allowing to benefit from preferences (Deloitte, 2013). A narrow object range also influences on fears against a different interpretation of tax regulations by Treasury authorities.

In an effect, the most popular tools supporting expenditures $\mathrm{R}+\mathrm{D}$ in Poland are subsidies. From a report, "Research-and-development activity of enterprises in Poland", results that from this form of support benefited $85 \%$ of surveyed enterprises, where $8 \%$ were benefiting from a tax relief to purchase technology (KPMG, 2013). It happens so, although there are obvious constraints connected with the application of 
subsidies like: extortion of convergence of conducted research with the criteria of granting subsidies, or high formalized process of granting and benefiting from subsidies.

Basing financial support for enterprises on subsidies, together with a defeat in a level of applying a tax relief for a purchase of technology, is one of the causes of low enterprises' engagement in $\mathrm{R}+\mathrm{D}$ works. Without enterprises activation in this field, Poland will be still on the lowest level from the view of investments in R+D among EU and OECD countries. Justification of such support, except from the benefits of enterprises, is that there are also external benefits taken by other enterprises and community. Negligence in this field will lead to durable reduction in international competitiveness level and can constitute a crucial destimulant in a long-term economic development.

Development of research-and-development activity is a key action leading to the growth of Poland's economy's innovativeness. To achieve this aim, one should implement to income tax construction paid by enterprises, a new tax relief, which would increase an object catalogue of expenditure R+D. Without such extension and simplification of regulations, reducing the interpretation field of Treasury institution, it will be difficult to include enterprises into a process of increasing research-and-development expenditures in Poland, and in a consequence in the process of rebuilding economy.

\section{REFERENCES}

Bronwyn H. Hall, Jacques Mairesse, and Pierre Mohnen, "Measuring The Returns To R\&D.” (2009),Working Paper 15622 (National Bureau of Economic Research), available at http://www.nber.org/papers/w15622.

Congressional Budget Office, "R\&D and Productivity Growth: A Background Paper" (2005), available at http://www. cbo.gov/doc. cfm?index $=6482$.

David T. Coe and Elhanan Helpman, “International R\&D Spillovers," European Economic Review 39 (5) (1995): 859-887

Dominique Guellec and Bruno van Pottelsberghe De La Potterie, "R\&D and Productivity Growth: Panel Data Analysis of 16 OECD Countries," OECD Economic Studies 33 (2001): 103-126.

David B. Audretsch and Maryann P. Feldman, "R\&D Spillovers and the Geography of Innovation and Production," American Economic Review 86 (3) (1996): 630.

Lee Fleming, Charles King III, and Adam I. Juda, "Small Worlds and Regional Innovation," Organization Science 18 (6) (2007): 938-954.

Zvi Griliches, “The Search for R\&D Spillovers," Scandinavian Journal of Economics 94(supplement), S29-S47, 2002.

Jeffrey I. Bernstein and M. Ishaq Nadiri, "Interindustry R\&D Spillovers, Rates of Return, and Production in High-Tech Industries,” American Economic Review 78 (2) (1988): 429-434.

Laura Tyson, Greg Linden: The Corporate R\&D Tax Credit and U.S. Innovation and Competitiveness

OECD, 2010. R\&D tax incentives: Rationale, design, evaluation. OECD Innovation Policy

Platform, November 2010.

Christian Köhler, Philippe Laredo, Christian Rammer, The Impact and Effectiveness of Fiscal Incentives for R\&D, Nesta Working Paper No. 12/01

OECD, 2009. Science, Technology and Industry Scoreboard 2009. OECD, Paris.

Główny Urząd Statystyczny, Nauka i technika w 2012 r., Informacje i opracowania statystyczne, Warszawa 2013.

OECD Science, Technology and Industry Scoreboard 2011, Tax incentives for business R\&D, http://dx.doi.org/10.1787/ sti_scoreboard-2011-en

Journal of Law,Dz. U. nr 74, poz. 397, 2011, Ustawa z dnia 15.02.1992 r. o podatku dochodowym od osób prawnych. Journal of Law, Dz. U. poz. 361, 2012, Ustawa z dnia 26.07.1991 r. o podatku dochodowym od osób fizycznych.

Pit.pl, Ulga na nowe technologie, data pobrania: 20.05.2014, http://www.pit.pl/ulga_na_nowe_technologie_komentarz_pit_interpretacje_3604.php 